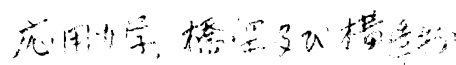

\title{
不静定構造物の弾性重心の拡張定義について
}

\author{
准員島田静 雄*
}

\section{DEFINITION OF ELASTIC CENTER IN STATICALLY INDETERMINATE STRUCTURES}

By Shizuo Shimada, C.E. Assoc. Member

\begin{abstract}
Synopsis: The elastic structures which have various inner or outer restrictions are statically indeterminate. The equilibrium equations are always simultaneous equations concerning the statically indeterminate forces. A method of affine-transformation induces an idea that is like an elastic center in affine space of n-order. The author shows a general explanation in the solutions of statically indeterminate structures.

要 旨 平面構造物に限らず, 一般に Hook の法則の適用できる弾性構造物が, 種々の内的括よび外 的な拘束を受けて不静定となつている時に，この構造物に加わる任意の力に対して不静定力の釣合条件 を求める式は多元一次方程式で与えられる。固定アーチの応力を求めるために仮想的に 設定した弾性重 心の概念をさらに一般化することにより不静定構造物の解を求める一つの方法が提出される。
\end{abstract}

\section{1. 静定基本形と不静定力}

ある高次の不静定構造物の応力を解析するために適当に 拘束を除外して構造物を静定状態に支持し，拘束状態 でその点に作用していた力を不静定力に考朰る。このように，ある不静定構造物を静定構造化したるのをある不 静定構造物の静定基本形と定義し，不静定の拘束条件を与える付加的な力を不静定力と呼ぶ。

ある不静定構造物の静定基本形の撰び方はいく種類も あり, かつその各場合について不静定力の表われ方は異 なつてくる。例えば 3 次の不静定構造物の例として 4 径 間連続析を考元る。通常連続析の応力解析をするには, 中間の支承の支承反力を不静定力に撰ぶか，をたは中間 の支承上の支承モーメントを不静定モーメントと考吕 る。図-1 4 径間連続析の静定基本形の撰び方と，そ れに付随した不静定力の撰び方の一例を示したものであ る。

不静定構造物の静定基本形は，かならずしも静定構造 にする必要はなく，任意の外力に対しての応力状態が既 知であるならば，より低次の不静定次数の構造物を静定 基本形之考えて差支えはない。例えば 2 径間の連続析を 4 径間連続桁を解く際の基本形に撰ぶことも可能であ る。この場合に, 静定と云う言葉を除いて単に基本形と 云うのが言葉の定義としては合理的である。

\section{図一1 4 径間連続杕の静定基本形と不静定力の取 り方の一例}

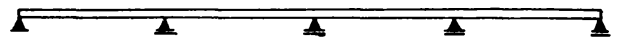

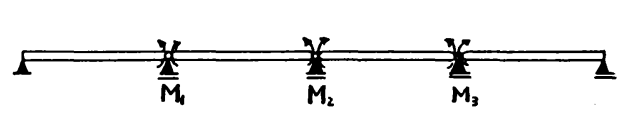
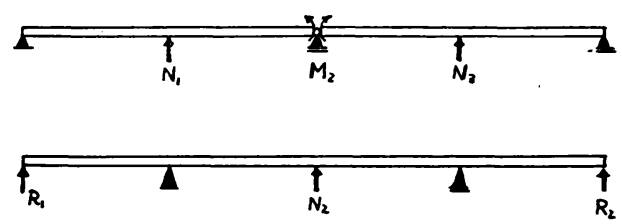

逆に静定を通り越して，実際には不安定な支持状態の析を基本形と考劣ると，数式の演算や法則に便利な事る ある。例えば総ての支承が弾性的なバネで支持されているバネ支承上の連続栴を解くよろな時に，この析の自由 振動解に全く外的な支持条件に無関係に 誘導する質点系の自由振動を取り扱うと, バネ常数が線型のパラメータ 一に入るだけで支承反力を求める演算が簡単になる ${ }^{1)}$

不静定構造物の解を求めるには，実際上どのような手段を用いても解く事それ自体は可能であるが，一番簡明 で実用になる方法を見出すのが大切である。それには静定基本形の撰び方にるよるが，弾性体の性質を利用した 解法の技術も多分飞影響を与えるものである。

\section{2. カと変位の関係を与える行列（変位のマトリックス）}

* 工学修士, 東京大学大学院学生, 工学部土木教室, 
弾性体の 2 点 $P$ 扰よひ $Q$ 亿作用している 2 つのを, その方向も考えて $F_{P}, F_{Q}$ とべクトルで表わす。いま $F_{P}=1$ の力が $P$ 点作用し， $P$ 点の位

図一2 カとその作用方向への 変位

置がべクトル $D_{P}$ で与えられる方向に変位したとする。同じょうに $\boldsymbol{F}_{Q}=1$ の力で $Q$ 点の変位が $D_{Q}$ で与兄られるする。 $F_{P}=1$ の力によつて $P$ 点が 変位するが, $Q$ 点も変位するであろろ。 $\boldsymbol{F}_{P}=1$ の力で移動する $Q$ 点の変位 を $D_{Q P}$ で与光, 同じ考光から $D_{P Q}$ も定義づけられる（図一2）。

$\boldsymbol{F}_{P}, \boldsymbol{F}_{Q}, \boldsymbol{D}_{P}, \boldsymbol{D}_{Q}, \boldsymbol{D}_{Q P}, \boldsymbol{D}_{P Q}$ のベクトル相互の関係を規定するすのが弾性 体の特質である。 $\boldsymbol{F}$ なる力と変位とが対応することにより, 弾性体にはエネ ルギー函数 $W$ が存在し得る。 $\boldsymbol{F}_{P}$ なるべクトルを単位ベクトルと考光, 力の 大きさをスカラー $\varphi_{P}$ で与えることとしよう。 $F_{P}, F_{Q}$ の 2 種の力が作用し た時, 弾性体に蓄えられた全内部弾性エネルギーの総和 $W$ は
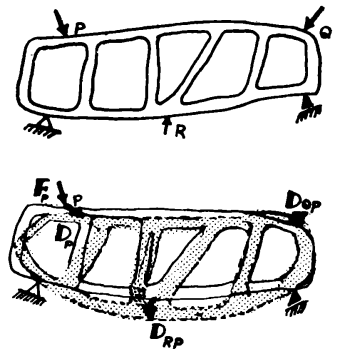

$$
W=\frac{1}{2} \varphi_{P}{ }^{2} \boldsymbol{F}_{P} \cdot \boldsymbol{D}_{P}+\frac{1}{2} \varphi_{Q}{ }^{2} \boldsymbol{F}_{Q} \cdot \boldsymbol{D}_{Q}+\varphi_{P} \varphi_{Q} \boldsymbol{F}_{P} \cdot \boldsymbol{D}_{P Q}
$$

Maxwell-Betit の法則で $\boldsymbol{F}_{P} \cdot \boldsymbol{D}_{P Q}=\boldsymbol{F}_{Q} \cdot \boldsymbol{D}_{Q P}$ が成立することは容易に証明できる。力と変位とのスカラ一積 $\boldsymbol{F} \cdot \boldsymbol{D}$ の持つ力学的な意味は, 力 $\boldsymbol{F}$ の $\boldsymbol{D}$ 方向飞為した仕事と云う意味を持つとともに, 変位 $\boldsymbol{D} の \boldsymbol{F}$ の作用方 向への成分を与える。 $\boldsymbol{F}_{P}, \boldsymbol{F}_{Q}$ を単位べクトルとすれば

$$
\boldsymbol{F}_{P} \cdot \boldsymbol{D}_{P}=\delta_{P P}, \dot{F_{Q}} \cdot \boldsymbol{D}_{Q}=\delta_{Q Q}, \boldsymbol{F}_{P} \cdot \boldsymbol{D}_{P Q}=\boldsymbol{F}_{Q} \cdot \boldsymbol{D}_{Q P}=\delta_{P Q}
$$

と書いて, エネルギー函数 $W$ が書き換兄られる。

$$
W=\frac{1}{2} \varphi_{P}{ }^{2} \delta_{P P}+\frac{1}{2} \varphi_{Q}{ }^{2} \delta_{Q Q}+\varphi_{P} \varphi_{Q} \delta_{P Q}
$$

$n$ コの点 $123 \cdots n$ 亿作用する力を，その作用方向を確実に定義してその大きさを $A_{1}, A_{2}, A_{3} \cdots A_{n}$ で与える。

(2) 式で定義した力とその方向への変位成分を計算すれば， $\delta_{11} \delta_{12} \delta_{13} \cdots \delta_{1 n}, \delta_{21} \delta_{22} \delta_{23} \cdots \delta_{2 n}, \delta_{31}, \delta_{32}, \delta_{33}, \cdots \delta_{3 n}$, $\cdots \delta_{n_{1}}, \delta_{n_{2}}, \delta_{n_{3}}, \cdots \delta_{n n}$ 計 $n^{2}$ コの数值が計算される。これを行列の形に表わし，変位のマトリックスと定義する。

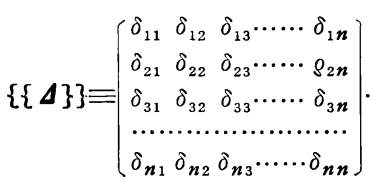

この行列は $\delta_{i j}=\delta_{j i}$ の関係があり対称である。この場合にもエネルギー函数が存在することでより有意義な展開 を可能とする。

3. エネルギー函数 $\boldsymbol{W}$ と二次形式

変位の行列 (4) を基準として, 力 $A_{1}, A_{2}, A_{3}, \cdots A_{n}$ をべクトルと考えて数式の演算に力学的な意味を与えな がら説明を進めてゆく。

$A_{1}, A_{2}, A_{3}, \cdots A_{n}$ の力が作用した時の各点の変位は

$$
\left\{\begin{array}{l}
D_{1}=A_{1} \delta_{11}+A_{2} \delta_{12}+A_{3} \delta_{13}+\cdots \cdots A_{n} \delta_{1 n} \\
D_{2}=A_{1} \delta_{21}+A_{2} \delta_{22}+A_{3} \delta_{23}+\cdots \cdots A_{n} \delta_{2 n} \\
D_{3}=A_{1} \delta_{31}+A_{2} \delta_{32}+A_{3} \delta_{33}+\cdots \cdots A_{n} \delta_{3 n} \\
\cdots \cdots \cdots \cdots \cdots \cdots \cdots \cdots \cdots \cdots \cdots \cdots \cdots \cdots \cdots \cdots \cdots \cdots \cdots \cdots \cdots \cdots \cdots \cdots \cdots \cdots \cdots \cdots \cdots \cdots \cdots \cdots \cdots \cdots \cdots \cdots \\
D_{n}=A_{1} \delta_{n 1}+A_{2} \delta_{n 2}+A_{3} \delta_{n 3}+\cdots \cdots A_{n} \delta_{n n}
\end{array}\right.
$$

この演算を簡略に表わすためにベクトルと行列の演算の記法が利用される。

$$
\boldsymbol{A} \equiv\left\{A_{1}, A_{2}, A_{3}, \cdots A_{n}\right\}, \quad \boldsymbol{D} \equiv\left\{D_{1}, D_{2}, D_{3}, \cdots D_{n}\right\}
$$

と招いて

$$
D \equiv\{\{\Delta\}\} \times A \equiv A \times\{\{\Delta\}\}
$$

さて力 $\boldsymbol{A}$ が弾性体に作用した時に, 弾性体に蓄えられェネルギーを $W$ とすれば

$$
W=\frac{1}{2}\left(A_{1} D_{1}+A_{2} D_{2}+A_{3} D_{3}+\cdots \cdots+A_{n} D_{n}\right)=\frac{1}{2} \boldsymbol{A} \cdot \boldsymbol{D}
$$

ここで $A$ と $\delta$ とで $W$ を書き換えて表わす。

$$
\begin{aligned}
2 W= & A_{1}{ }^{2} \dot{\delta}_{11}+A_{1} A_{2} \delta_{12}+A_{1} A_{3} \delta_{13}+\cdots \cdots+A_{1} A_{n} \delta_{1 n} \\
& +A_{2} A_{1} \delta_{21}+A_{2}{ }^{2} \delta_{22}+A_{2} A_{3} \delta_{23}+\cdots \cdots+A_{2} A_{n} \delta_{2 n} \\
& +A_{3} A_{1} \delta_{31}+A_{3} A_{2} \delta_{32}+A_{3}{ }^{2} \delta_{33}+\cdots \cdots+A_{3} A_{n} \delta_{3 n}
\end{aligned}
$$




$$
+A_{n} A_{1} \delta_{n_{1}}+A_{n} A_{2} \delta_{n_{2}}+A_{n} A_{3} \delta_{n 3}+\cdots \cdots+A_{n}{ }^{2} \delta_{n n}
$$

この $A$ の 2 重積の和として示される形を, アフィノールの演算の記法に従觉ば次のごとき簡単な表現形式となる。

$$
2 W=A \cdot D=A \cdot[\{\{\Delta\}\} \times A]=A \times\{\{\Delta\}\} \times A=\{\{\Delta\}\} \times A=\{\{\Delta\}\}:\{A \times A\}
$$

ここに $\{\boldsymbol{A} \times \boldsymbol{A}\}$ はアフィノールであり, エネルギー $W$ はマトリックス $\{\{\boldsymbol{\Delta}\}\}$ とアフィノール $\{\boldsymbol{A} \times \boldsymbol{A}\}$ のス カラー積で与えられる。 $W$ を $A$ 飞関して二度偏微分したものが変位の成分を与える。

$$
\frac{\partial^{2} W}{\partial A_{i}{ }^{2}}=\delta_{i i} \frac{\partial^{2} W}{\partial A_{i} \partial A_{j}}=\frac{\partial^{2} W}{\partial A_{j} \partial A_{i}}=\delta_{i j}=\delta_{j i}
$$

さて 1 組の力 $A_{1}, A_{2}, A_{3}, \cdots A_{n}$ を取り扱う時飞, 演算は $n$ 次のベクトルと考光た。今この 1 組の力をとの简々 の大きさの此を一定保つたままで丁度一つの力と同じょうに取り扱うことを考学る。 $\boldsymbol{A}_{\boldsymbol{i}}$ と云うべクトルを単位 のベクトルとし, 大きさを与えるのは $\varphi_{i}$ なるカラーで正負大小を規定させる。これによつて, ある1組の力は $\boldsymbol{A}_{\boldsymbol{i}}$ なるべクトルの1次式で示される。

$$
\boldsymbol{A} \equiv \varphi_{1} \boldsymbol{A}_{1}+\varphi_{2} \boldsymbol{A}_{2}+\varphi_{3} \boldsymbol{A}_{3}+\cdots \cdots \varphi_{n} \boldsymbol{A}_{n}
$$

$\boldsymbol{A}_{\boldsymbol{i}}(i=1,2,3, \cdots \cdots n)$ の種々の組合わせであらゆる荷重状態を表わす事が可能であるのは， $n$ コのベクトルは互 いに1次独立でなければならない。 $A_{i}$ のように, $n$ コの力を 1 組に考えて丁度 1 つの力と同じょうに取り扱うの が高次の不静定構造物を取り扱う際には便利なことが多い。いま， $\boldsymbol{A}_{i}, \boldsymbol{A}_{j}$ の 2 つのべクトルで示される力があつ てこの力が作用した時の弾性体のエネルギーを考える。 $A_{i}$ が作用した時の変位を $D_{i}, A_{j}$ が作用した時の変位 を $\boldsymbol{D}_{\boldsymbol{j}}$ で表わすと

$$
D_{i} \equiv A_{i} \times\{\{\Delta\}\}, D_{j} \equiv\{\{\Delta\}\} \times A_{j}
$$

2 種のべクトルの組合わせで得られる力 $\varphi_{i} A_{i}+\varphi_{j} A_{j}$ によつて, 弾性体に蓄えられるエネルギーを $W$ とすれば

$$
\begin{aligned}
2 W & =\left[\varphi_{i} \boldsymbol{A}_{i}+\varphi_{j} \boldsymbol{A}_{j}\right] \times\{\{\boldsymbol{\Delta}\}\} \times\left[\varphi_{i} \boldsymbol{A}_{i}+\varphi_{j} \boldsymbol{A}_{j}\right] \\
& =\varphi_{i}{ }^{2}\{\{\boldsymbol{\Delta}\}\}:\left\{\boldsymbol{A}_{\boldsymbol{i}} \times \boldsymbol{A}_{i}\right\}+\varphi_{j}{ }^{2}\{\{\boldsymbol{\Delta}\}\}:\left\{\boldsymbol{A}_{j} \times \boldsymbol{A}_{j}\right\}+2 \varphi_{i} \varphi_{j}\{\{\boldsymbol{\Delta}\}\}:\left\{\boldsymbol{A}_{\boldsymbol{i}} \times \boldsymbol{A}_{j}\right\} \\
& =\varphi_{i}{ }^{2} \boldsymbol{A}_{\boldsymbol{i}} \cdot \boldsymbol{D}_{\boldsymbol{i}}+\varphi_{j}{ }^{2} \boldsymbol{A}_{j} \cdot \boldsymbol{D}_{j}+\varphi_{i} \cdot \varphi_{j} \boldsymbol{A}_{\boldsymbol{i}} \cdot \boldsymbol{D}_{j}+\varphi_{i} \varphi_{j} \boldsymbol{A}_{j} \cdot \boldsymbol{D}_{\boldsymbol{i}}
\end{aligned}
$$

$\boldsymbol{A}_{i} \cdot D_{j}$ は $\boldsymbol{A}_{j}$ なる力が作用した時に $\boldsymbol{A}_{i}$ の作用方向に為した仕事であり， $\boldsymbol{A}_{j} \cdot D_{i}$ は $\boldsymbol{A}_{\boldsymbol{i}}$ なる力が作用した時 飞 $\boldsymbol{A}_{j}$ の作用方向飞為した仕事である。これは Maxwell-Betit の法則で $\boldsymbol{A}_{\boldsymbol{i}} \cdot \boldsymbol{D}_{\boldsymbol{j}}=\boldsymbol{A}_{\boldsymbol{j}} \cdot \boldsymbol{D}_{\boldsymbol{i}}$ が常に成立する。特

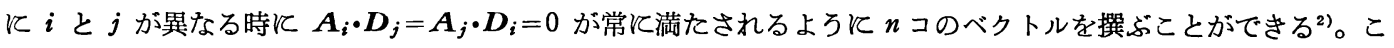
の時には $\boldsymbol{A}_{\boldsymbol{i}}$ なる力は他の $\boldsymbol{A}_{j}$ なる力の作用方向には仕事をしない。このような $n$ コの力のべクトルをアフィン カまたはアフィン荷重と便宜的に呼んでいるが, ドイツ語の Affinlasten, Affinlastgruppen の適当な邦訳が見つ からないのでこの妙な言葉を使用する。アフィン荷重の大きさの単位は適当な単位ベクトルで与えその正負大小 はスカラーで決定する。

いま $A_{i}(i=1,2,3, \cdots n)$ をアフィン荷重とし，任意の力の作用状態が (8) 式で示されるようと $n$ コのアフィ ン荷重の 1 次形式で与えられる時に，弾性体に蓄えられるエネルギーがどのような形になるかを誘導してみる。

力は

$$
\boldsymbol{A} \equiv \varphi_{1} \boldsymbol{A}_{1}+\varphi_{2} \boldsymbol{A}_{2}+\varphi_{3} \boldsymbol{A}_{3}+\cdots \cdots \cdots \varphi_{n} \boldsymbol{A}_{n}
$$

変位は

$$
\boldsymbol{D} \equiv \varphi_{1} \boldsymbol{D}_{1}+\varphi_{2} \boldsymbol{D}_{2}+\varphi_{3} \boldsymbol{D}_{3}+\cdots \cdots \cdots \varphi_{n} \boldsymbol{D}_{\boldsymbol{n}}
$$

よって弾性仕事 $W$ は $\frac{1}{2} A \cdot D, A_{i} \cdot D_{j}=0, i \neq j$ を考虑して整理すれば

$$
\begin{aligned}
W= & \frac{1}{2} \varphi_{1}{ }^{2} \boldsymbol{A}_{1} \cdot \boldsymbol{D}_{1}+\frac{1}{2} \varphi_{2}{ }^{2} \boldsymbol{A}_{2} \cdot \boldsymbol{D}_{2}+\frac{1}{2} \varphi_{3}{ }^{2} \boldsymbol{A}_{3} \cdot \boldsymbol{D}_{3}+\cdots \cdots \frac{1}{2} \varphi_{n}{ }^{2} \boldsymbol{A}_{\boldsymbol{n}} \cdot \boldsymbol{D}_{\boldsymbol{n}} \\
= & \frac{1}{2} \varphi_{1}{ }^{2}\left\{\boldsymbol{A}_{1} \times \boldsymbol{A}_{1}\right\}:\{\{\Delta\}\}+\frac{1}{2} \varphi_{2}{ }^{2}\left\{\boldsymbol{A}_{2} \times \boldsymbol{A}_{2}\right\}:\{\{\Delta\}\}+\frac{1}{2} \varphi_{3}{ }^{2}\left\{\boldsymbol{A}_{3} \times \boldsymbol{A}_{3}\right\}:\{\{\Delta\}\} \\
& +\cdots \cdots \frac{1}{2} \varphi_{n}{ }^{2}\left\{\boldsymbol{A}_{n} \times \boldsymbol{A}_{n}\right\}:\{\{\Delta\}\}
\end{aligned}
$$

Wを力で偏微分するには, 力がベクトルであっても差しつかえはない。ただ $\boldsymbol{A}_{i}$ は単位のべクトルを示すから変 数をスカラーに置き換えて理解しなければならない。

$$
\frac{\partial^{2} W}{\partial \boldsymbol{A}_{i} \partial \boldsymbol{A}_{j}}=\frac{\partial^{2} W}{\partial \varphi_{i} \partial \varphi_{j}}=\boldsymbol{A}_{i} \cdot \boldsymbol{D}_{j}=0, \frac{\partial^{2} W}{\partial \boldsymbol{A}_{i} \partial \boldsymbol{A}_{i}}=\frac{\partial^{2} W}{\partial \varphi_{i} \partial \varphi_{i}}=\boldsymbol{A}_{i} \cdot \boldsymbol{D}_{i}=k_{i i}
$$

特飞 $k_{i i}$ の常数をアフィン荷重の個有值と呼び, 弾性体である限り $k_{i i}>0$ である。 $k_{i i}$ が負になることはあり得 ない。 $k_{i i}$ は常にアフィン荷重に個有するるのであり, もし 0 となる常数が存在するならば, この弾性体の支持 が不安定であることを意味する。 


\section{4. 変位のマトリックスのアフィン展開}

変位のマトリックス $\{\{\boldsymbol{\Delta}\}\}$ と $n$ コのアフィン荷重 $\boldsymbol{A}_{i}$ が求まつている時に, 変位のマトリックスは次のアフ ィン展開を可能にする。

$$
\{\{\Delta\}\}=\frac{1}{k_{11}}\left\{D_{1} \times D_{1}\right\}+\frac{1}{k_{22}}\left\{D_{2} \times D_{2}\right\}+\frac{1}{k_{33}}\left\{D_{3} \times D_{3}\right\}+\cdots \cdots \frac{1}{k_{n n}}\left\{D_{n} \times D_{n}\right\}
$$

変位のマトリックスの逆マトリックスは, アフィン荷重を与えるべクトルで次のアフィン標示となる。

$$
\left\{\left\{\Delta^{-1}\right\}\right\} \equiv \frac{1}{k_{11}}\left\{A_{1} \times A_{1}\right\}+\frac{1}{k_{22}}\left\{A_{2} \times A_{2}\right\}+\frac{1}{k_{33}}\left\{A_{3} \times A_{3}\right\}+\cdots \cdots \frac{1}{k_{n n}}\left\{A_{n} \times A_{n}\right\}
$$

(10) 式扣よび (11) 式は, 対称なマトリックスの逆マトリックスを計算するのに使用される関係式である。

\section{5. 不静定構造物のアフィン荷重}

不静定構造物の解を求める際に， ある静定支持状態を基本に考劣て，拘束条件と不静定力を対応させる。この 時に, この不静定力を計算するための境界条件は, その不静定力が全体の弾性仕事を考えた時に仕事成分を持た ないとして与える。すなわち $A_{1}, A_{2}, A_{3}, \cdots A_{n}$ なる力に対して，外为を含めた全弾性エネルギー $W$ の偏微分が 0 となるとする。

$$
\frac{\partial W}{\partial A_{1}}=\frac{\partial W}{\partial A_{2}}=\frac{\partial W}{\partial A_{3}}=\cdots \cdots \frac{\partial W}{\partial A_{n}}=0
$$

力に対しての偏微分は，力の 1 組を考えたベクトルでも成立しなければならない。

$$
\frac{\partial W}{\partial \boldsymbol{A}_{1}}=\frac{\partial W}{\partial \boldsymbol{A}_{2}}=\frac{\partial W}{\partial \boldsymbol{A}_{3}}=\cdots \cdots=\frac{\partial W}{\partial \boldsymbol{A}_{n}}=0
$$

いま $A_{1}, A_{2}, A_{3}, \cdots A_{n}$ なる $n$ コの不静定力の相互の変位を変位のマトリックスで与える。力とその作用方向へ の変位は, 基本形で計算されるもので, 得られるマトリックスは対称である。 $\boldsymbol{A}_{i}(i=1,2,3, \cdots n)$ をこのマトリ ックスから導いたアフィン荷重と考学る。 $\boldsymbol{A}_{i}$ は弾性体の基本形に関してエネルギーの直交性があるから，アフィ ン荷重は, $n$ 次元空間の弾性重心飞作用する不静定力と考学ることができる。固定アーチでは，仮想的な中心を 考劣てそこ作用する 3 つの力, 水平力 $H$, 垂直力 $V$, モーメント $M$ を 不静定力に撰ベば, これら 3 つ力が互いに独立で他の変位に無関係で ある性質がある（図一3）。

仮想的な弾性重心は何も中心を作る必要はなく, 弾性重心と作用する 力は, 支承作用する 1 組の力と全く同じであるから，この 1 組の力が 弾性重心に作用する力と同じに，エネルギーの直交性が満たされれば,

\section{図一3 弾性重心の想定}

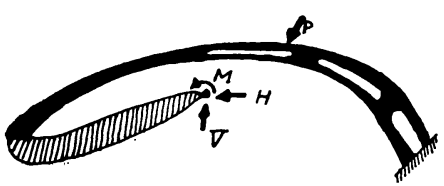
故意に弾性重心を深す必要は認めない。固定アーチ, 固定ラーメンを解く際には, 幾何学的に弾性中心を計算す ることができるが，同じ 3 次の不静定では，中間の支承の反力を不静定力と撰べば，これらの力は総て同じ方向 を向くから幾何学的に弾性重心などは存在し得ないことになる。

そこで, 固定アーチの弾性重心と作用する 3 つの不静定力がェネルギーに関して互に直交する性質のみをより 広く利用するためと, $n$ 次の不静定構造の不静定力を仮想的飞考兄に $n$ 次のアフィン空間の弾性重心に働く $n$ コ の力に取ることを考光，これをアフィン荷重と名ずけることにした。アフィン荷重はベクトルとして計算される ようにいくつかの力の 1 組を丁度 1 つの力と同じように取扱う。

\section{6. アフィン荷重の影䈏線}

$P=1$ の外力が不静定構造物のある任意の場所に作用していた時に, 不静定力がどの程度の大きさであるかを求 めるのが究極には問題となる。 $P=1$ の外力が常に 1 点だけと留まっていることは稀であり, 不静定力の影響線を 連続的に知る方法が必要となる。これは非常に常識的な方法で精解が容易に得られる。

いま弾性体注 $\varphi_{1} \cdot \boldsymbol{A}_{1}, \varphi_{2} \boldsymbol{A}_{2}, \varphi_{3} \boldsymbol{A}_{3}, \cdots \cdots \varphi_{n} \boldsymbol{A}_{n}$ なる不静定力と, 外力としての $P$ が加わつて釣合い, かつす

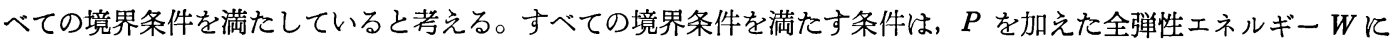
関して (12) 式が成立することを意味している。

$\boldsymbol{A}_{i}$ 飞関する偏微分は, 次の形になる。

$$
\begin{array}{r}
\frac{\partial W}{\partial \boldsymbol{A}_{i}}=\frac{\partial W}{\partial \varphi_{i}}=\int \frac{\partial^{2} W}{\partial \varphi_{i} \partial \varphi_{i}} \Delta \varphi_{i}+\int \frac{\partial^{2} W}{\partial \varphi_{i} \partial P} \Delta P=0 \\
\therefore \quad \frac{\partial^{2} W}{\partial \varphi_{i} \partial \varphi_{i}} \varphi_{i}+\frac{\partial^{2} W}{\partial \varphi_{i} \partial P} P=0 \ldots \ldots \ldots \ldots \ldots \ldots \ldots \ldots \ldots \ldots \ldots \ldots \ldots \ldots \ldots \ldots \ldots \ldots \ldots \ldots
\end{array}
$$

ここで $\partial^{2} W / \partial \varphi_{i} \cdot \partial \varphi_{i}$ は (9) 式により $k_{i i}$ 。次に $\partial^{2} W / \partial \varphi_{i} \partial P$ であるが, これの持つ力学的な意味は興味がある。 


$$
\begin{aligned}
\frac{\partial^{2} W}{\partial \varphi_{i} \partial P} & =\left[P=1 \text { がアフィン荷重 } A_{i}\right. \text { の作用方向に為した弾性仕事] } \\
& =\left[\text { 単位のアフィン荷重 } A_{i} \text { が, } P=1\right. \text { の作用方向に為した弾性仕事] }
\end{aligned}
$$

静定基本形に $P=1$ がある位置に作用した時に, 不静定力の方向への変位を

$$
\delta_{1 P}, \delta_{2 P}, \delta_{3 P}, \cdots \cdots \cdots \delta_{n P}
$$

アフィン荷重の箇々の力を

とすれば

$$
A_{i 1}, A_{i 2}, A_{i 3}, \cdots \cdots \cdots A_{i n}
$$

$$
\frac{\partial^{2} W}{\partial \varphi_{i} \partial P}=\delta_{1 P} \cdot A_{i_{1}}+\delta_{2 P} A_{i_{2}}+\delta_{3 P} A_{i_{3}}+\cdots \cdots \delta_{n P} A_{i n}
$$

$\boldsymbol{A}_{i}$ の単位のアフィン荷重が静定基本形に作用した時の, $P=1$ の作用点の変位を $\delta_{i P}$ とすれば

$$
\frac{\partial^{2} W}{\partial \varphi_{i} \partial P}=\delta_{i P}
$$

よつて $\varphi_{i}$ は次式で与えられる。

$$
\varphi_{i}=-\frac{1}{k_{i i}} \delta_{i P}
$$

特に $P=1$ が総て鉛直方向の荷重だけである時, $P=1$ が $x$ そ作用するとし， $A_{i}$ が静定基本形に加わつた時の 静定基本形のたわみ図を $\delta_{i}(x)$ で与兄れば, アフィン荷重の影響線 $\varphi_{i}(x)$ は, 個有值 $k_{i i}$ と共に

$$
\underline{\varphi_{i}(x)=-\frac{1}{k_{i i}} \delta_{i}(x)}
$$

アフィン荷重の影響線は，静定基本形に作用させた単位のアフィン荷重による変位図を $\left(-k_{i i}\right)$ で除した曲線で ある。

これが法則であり, 今後のあらゆる不静定構造物の解法の根幹となる重要な性質である。

\section{7. 連続杕の解法の 1 例}

図-4

\section{A) 単純枌を静定基本形に撰んだ場合（図一4）}

3 径間の連続妳の応力を解析するために, 静定基 本形は中間の支承を外した両端で単純に支持した枌 之考光, 不静定力は中間の支承の支承反力 $N_{1}, N_{2}$ 飞撰ぶ。静定基本形で $N_{1}=1$, および $N_{2}=1$ が作 用した時のその方向への変位を求める。

$$
\{\{\Delta\}\} \equiv \frac{l_{1}{ }^{3}}{18 E J}\left[\begin{array}{ll}
8 & 7 \\
7 & 8
\end{array}\right]
$$

アフィン荷重は $A_{1} \equiv\{1,1\}, A_{2} \equiv\{1,-1\}$ の 2 種 であり, 個有值は次の值である。

$$
k_{11}=\frac{5 l_{1}{ }^{3}}{3 E J} \quad k_{22}=\frac{l_{1}{ }^{3}}{9 E J}
$$

$\boldsymbol{A}_{1}, \boldsymbol{A}_{2}$ の影響線は, この力を静定基本形に作用さ せた時の枌の変位図 $\delta_{1}(\boldsymbol{x}), \delta_{2}(\boldsymbol{x})$ をそれぞれの個 有值 $\left(-k_{11},-k_{22}\right)$ で除した曲線である。

連続析の応力の影響線を求めるには, 静定基本形 にアフィン荷重が作用した時の静定基本形のたわ み, 曲げモーメント, せん断力, 支承反力等はあら かじめ計算されているものとして，これを $\delta_{1}(\boldsymbol{x})$, $\delta_{2}(x), \eta_{1}(x), \eta_{2}(x), \zeta_{1}(x), \zeta_{2}(x), r_{1}(A), r_{2}(A)$ とする。静定基本形㳊用する $P=1$ の荷重による 影響線を常々指標 0 を付して区別する。連続柞の任 意の点 $x_{1}$ のたわみの影響線

$$
\grave{o}\left(x, x_{1}\right)=\delta^{0}\left(x, x_{1}\right)+o_{1}\left(x_{1}\right) \varphi_{1}(x)+o_{2}\left(x_{1}\right) \varphi_{2}(x)
$$
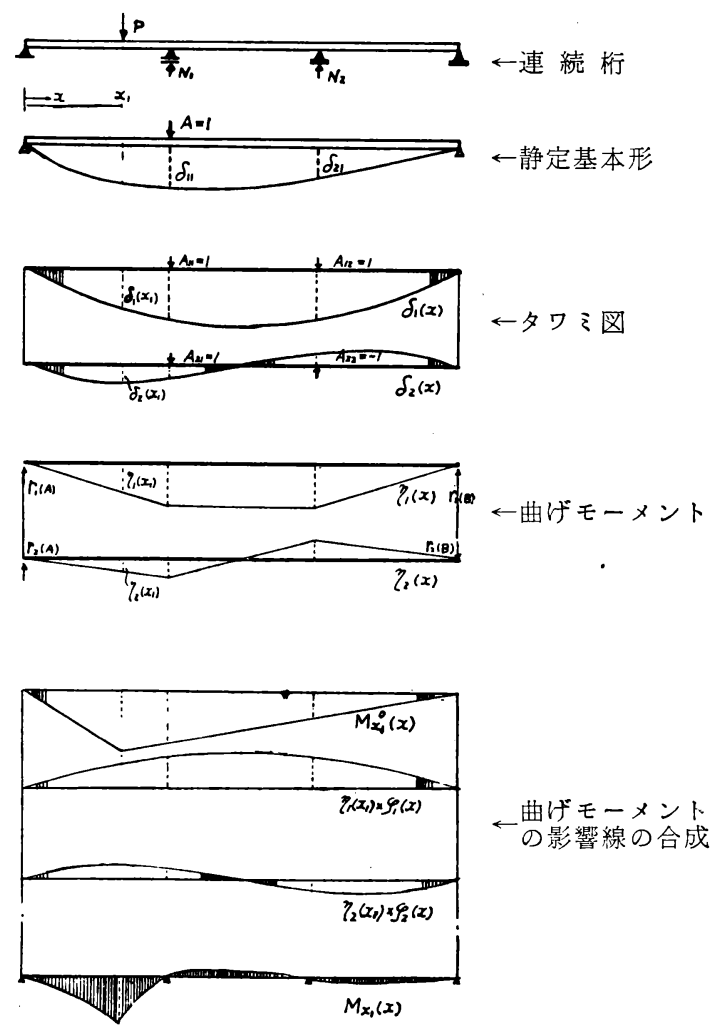

曲げモーメント の影響線の合成 
連続枌の任意の点 $x_{1}$ の曲げモーメントの影響線

$$
\boldsymbol{M}_{\boldsymbol{x}_{1}}(\boldsymbol{x})=\boldsymbol{M}_{\boldsymbol{x}_{1}}{ }^{0}(\boldsymbol{x})+\eta_{1}\left(\boldsymbol{x}_{1}\right) \varphi_{1}(\boldsymbol{x})+\eta_{2}\left(\boldsymbol{x}_{1}\right) \varphi_{2}(\boldsymbol{x})
$$

連続枌の任意の点 $x_{1}$ のせん断力の影響線

$$
S_{x_{1}}(x)=S_{x_{1}}{ }^{0}(x)+\zeta_{1}\left(x_{1}\right) \varphi_{1}(x)+\zeta_{2}\left(x_{2}\right) \varphi_{2}(x) .
$$

支承 $A$ の支承反力 $R_{A}$ の影響線

$$
R_{A}(x)=R_{A}^{0}(x)+r_{1}(A) \varphi_{1}(x)+r_{2}(A) \varphi_{2}(x)
$$

これらの影響線を求める式の形が総べて同じ形となるのに注意されたい。不静定の支承反力 $N_{1}$ を求めるのは, アフィン荷重 $\boldsymbol{A}_{1}, \boldsymbol{A}_{2}$ の各組成 $\boldsymbol{A}_{1} \equiv\left\{A_{11}, A_{12}\right\}, \boldsymbol{A}_{2} \equiv\left\{A_{21}, A_{22}\right\}$ の和で与号れる。

$$
\begin{aligned}
& N_{1}(x)=A_{11} \varphi_{1}(x)+A_{21} \varphi_{2}(x) \\
& N_{2}(x)=A_{12} \varphi_{1}(x)+A_{22} \varphi_{2}(x)
\end{aligned}
$$

B） 3 つの連続する単純析を静定基本形に撰んだ場合（図一5）

3 径間の連続析の不静定力を中間の支承での析の曲 ゲモーメントに取る。静定基本形は中間の支承上で桁 を切断して，ヒンジとみなす。不静定力を支承の曲げ モーメント $M_{1}, M_{2}$ とし, 静定基本形で $M_{1}=1$, 括よ び $M_{2}=1$ が作用した時のその方向への変位を求める。 力は曲げモーメントであるので, 変位は廻転角で与え られる。

$$
\{\{\Delta\}\} \equiv \frac{l_{1}}{6 E J}\left[\begin{array}{ll}
4 & 1 \\
1 & 4
\end{array}\right]
$$

アフィン荷重は $\boldsymbol{A}_{1} \equiv\{1,1\}, \boldsymbol{A}_{2} \equiv\{1,-1\}$ の 2 種に 撰ベる。個有值は次の值である。

$$
k_{11}=\frac{10 l_{1}}{6 E J} \quad k_{22}=\frac{l_{1}}{E J}
$$

アフィン荷重の影響線はアフィン荷重が静定基本形に 作用した時のたわみ図を個有值で除した形で与えられ
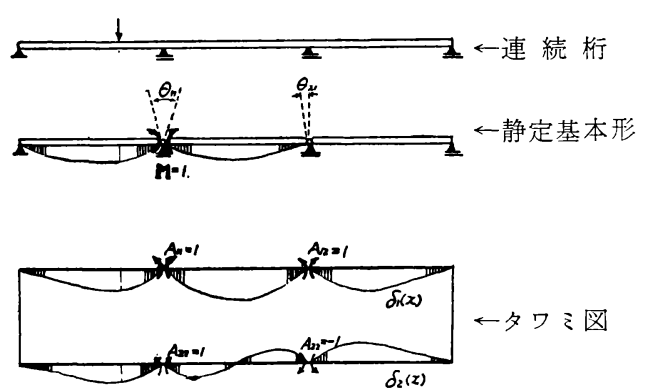

る。応力の影響線を求める基本式は (15)〜 (20) 式で ある。 $\delta(\boldsymbol{x}), \eta(\boldsymbol{x})$ 等は, 静定基本形の撰び方が異な れば違つた形で与えられるが, 究極に得られる連続析 の性質は結局同じものが得られる。

\section{8. 後 記}

連続析の応力解析に， 3 連モーメントの定理が用い られる。この際の釣合条件式は不静定の支承モーメン トに関する連立一次方程式を解くことになる。通常と の形は下式のように得られる。
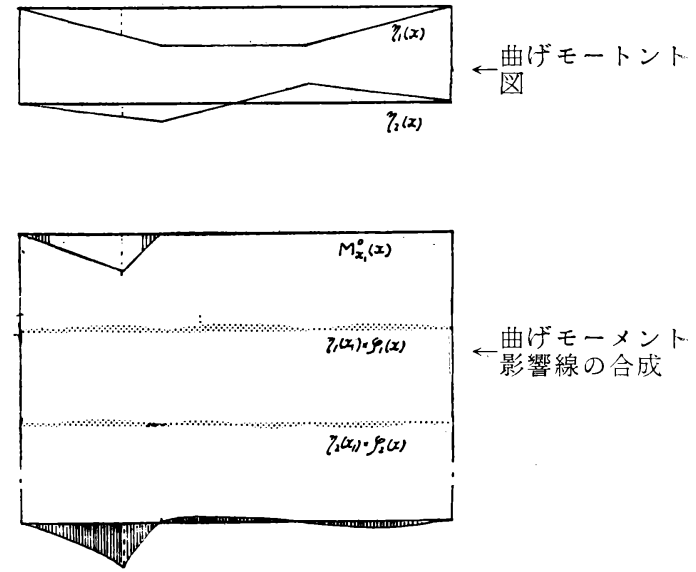

$$
\begin{aligned}
2\left(l_{1}+l_{2}\right) M_{1}+l_{2} M_{2} & =p_{1} \\
l_{2} M_{1}+2\left(l_{2}+l_{3}\right) M_{2}+l_{3} M_{3} & =p_{2} \\
l_{3} M_{2}+2\left(l_{3}+l_{4}\right) M_{3}+l_{4} M_{4} & =p_{3}
\end{aligned}
$$

右辺の荷重項は外力による数值である。この連立方程式の $M$ の係数は, 静定基本形を支承の上でヒンジにした 形にした時の変位のマトリックスで与えられる。アフィン荷重とそのたわみ罒で 不静定構造を解析するとは, 右 辺の荷重項を全然考慮する必要がないのが特色である。

\section{参考 文 献}

1) Leohardt, Ardrä: Die Vereinfachte Trägerrostbeechnung, S 65

2）近藤繁人：立体構造物の静定主系の選び方について，土木学会論文集 35 号 